\title{
Transcriptome sequencing of Eucalyptus camaldulensis seedlings subjected to water stress
}

\author{
Bala Thumma \\ From IUFRO Tree Biotechnology Conference 2011: From Genomes to Integration and Delivery \\ Arraial d'Ajuda, Bahia, Brazil. 26 June - 2 July 2011
}

\begin{abstract}
Water stress limits plant survival and production in many parts of the world. Identification of genes responding to water stress conditions will underpin efforts to breed plants better adapted to drought. We studied the effect of water stress on Eucalyptus camaldulensis seedlings derived from three natural populations. Physiological and growth traits were measured and gene and allelic expression in leaves was examined by RNA sequencing (RNA-seq). Water stress had a significant impact on all the physiological and growth traits, while differences between the populations were not significant. Genes differentially expressed in leaves were identified by de novo assembly and by ab initio transcriptome mapping using the Eucalyptus grandis reference genome sequence. Gene ontology (GO) enrichment tests with 2,500 significantly differentiated genes revealed 128 stress-related gene categories were up-regulated while 28 gene categories belonging to photosynthesis and other metabolic processes were down-regulated under stress treatment. More than 190,000 single nucleotide polymorphisms (SNPs) and small indels were detected and 4,053 of these revealed differential allelic expression between control and drought stressed seedlings. Allelic expression of $70 \%$ of these variants was correlated with total gene expression. These variants may be cis-acting variants or in high linkage disequilibrium with such variants. The SNPs and indels identified in this study form a useful resource for further testing in association studies.
\end{abstract}

Published: 13 September 2011

Correspondence: reddy.thumma@csiro.au

CSIRO Plant Industry, Australia

(c) 2011 Thumma; licensee BioMed Central Ltd. This is an open access article distributed under the terms of the Creative Commons Attribution License (http://creativecommons.org/licenses/by/2.0), which permits unrestricted use, distribution, and reproduction in any medium, provided the original work is properly cited.
doi:10.1186/1753-6561-5-S7-031

Cite this article as: Thumma: Transcriptome sequencing of Eucalyptus camaldulensis seedlings subjected to water stress. BMC Proceedings 2011 5(Suppl 7):O31.
Submit your next manuscript to BioMed Central and take full advantage of:

- Convenient online submission

- Thorough peer review

- No space constraints or color figure charges

- Immediate publication on acceptance

- Inclusion in PubMed, CAS, Scopus and Google Scholar

- Research which is freely available for redistribution \\ () Biomed Central}

